\title{
Gold Currency (Gold Dinar) in Gresham's Law 'Bad Money Drive Out Good Money': A Review
}

\author{
Salmy Edawati Yaacob \\ Mat Noor Mat Zain \\ Zamzuri Zakaria \\ Nik Abdul Rahim Nik Abdul Ghani \\ Azlin Alisa Ahmad \\ Research Centre for Sharia \\ Faculty of Islamic Studies \\ Universiti Kebangsan Malaysia
}

\begin{abstract}
Gold dinar or gold currency has been practiced in several areas in Malaysia, Indonesia and South Africa. The uniqueness of gold currency as a storage of value, intrinsic value and stable is often discussed among economist and financial experts. However, the opposition should be focused on the Gresham's Law in gold currency for the current implementation of the banknote. This research is a qualitative study by doing analytical review of previous studies to assess the position of gold currency in Gresham's law. The study found that the implementation of gold dinar together with the banknotes (Ringgit Malaysia) in Malaysia is in line with the concept of Gresham's Law. The society will keep gold dinar (because of the most valuable taste) and will choose to use banknotes (ringgit Malaysia) in daily transactions. This situation shows a clear situation that occurs 'Bad Money Drive Out Good Money'. This proves the difficulty of implementing a holistic gold currency if paper money is still in use.
\end{abstract}

Keywords: Gold currency, gold dinar, Gresham's Law, gold money, monetary

\section{Introduction}

The gold-based monetary system has been proven in a historic and empirical basis on its ability to maintain a currency value stability and reduce inflation rate compared to the fiat money system (Bordo 1993, SalmyEdawati 2012). Gold and silver currency also meets the characteristics of Islamic currencies which have been mentioned in the Qur'an and al-Hadith and meet the views of the Islamic scholars. In addition, this bimetallic currency has almost met all the functions and theories of currencies outlined by the classic and modern economists compared to other commodities. The mechanism is the mechanism of physical use of gold dinars as currency (FDE) and the mechanism of use of gold dinars as a backup of value (SDE). Gresham's Law is the theory of 'Bad Money Drive Out Good Money'. 'Bad money' means money that has no intrinsic value, whose currency face value is lower or not equal to the actual value. This currency exists in circulation with other currencies which have higher intrinsic value whereas from legal point it is accepted and considered as equivalent. It is said to be bad because it does not have content value and if it loses its face value according to legal-tender laws, then the money cannot be exchanged at any value. The modern fiat money generally is bad money because fiat money has replaced commodity money and has no value to change value. Hence, this article is intended to see the implementation of gold currency by Gresham's Law.

\section{Literature Review}

\subsection{Gresham's Law}

According to Greenfield \& Rockoff (1995), The theory of 'Bad Money Drive Out Good Money' or bad money theory (no intrinsic value) evict good money (has intrinsic value) was introduced by Sir Thomas Gresham (15191579) during the Tudor dynasty period. The theory was popular through 'Gresham's Law' but indirectly there were several literary figures and classical economists who told the same situation as the Gresham's Law. These include:

i) Theognis (end of the 6th century and early 5th century S. M)

Theognis is a professional of sad poems. He lived before the birth of Sir Thomas Gresham (i.e. 20 centuries before the birth of the Gresham). The terms or bytes used by Theognis relating to the Gresham's Law are (Mundell 1998):

-"an eloquent and strongly biased witness of the struggle of the old aristocracy"- This idea is a traditional idea where part of views and ideas are accepted and partly eliminated with the increase in the lower class 
-"alloyed gold and silver is easily detected by a shrewd man." His writing in the Book of Maxims which means that "gold and silver is a alloy easily detected by a clever man."

-"Nor will anyone take in exchange worse when better is to be had."- This expression means "no one will take much worse exchange when there is better to give".

\section{i) Aristophanes (450-385 S.M)}

Aristophanes wrote inThe Frogs "the full-bodied coins that are the pride of Athens are never used while the mean brass coins pass hand to hand..." This expression means "the coin that has full value (intrinsic value) is the pride of Athens and has never used while the copper coins always exchange hands into hands..."(Mundell 1998).

\section{ii) Al-Maqrizi (1250-1517)}

According to Hassan (1999), the first man who discovered this theory was a Muslim economist, al-Maqrizi. AlMaqrizi has written about this law during the time of the Mamluk dynasty when the Mamluk has printed fulus (copper) with dinars and dirham currency. The situation saw fulus (as bad money) was circulating in the market and dinars as well as dirham (as good money) was kept by the Mamluks for the guarantee of gold and silver. Gold has its intrinsic value as an industrial commodity, while fulus is not supported with precious metals like gold and silver. The intrinsic value of fulus money compared to gold and silver will easily be affected by the fall of value(Hassan 1999; Salmy Edawati 2014).

In addition, Selgin (1996), explaining 'good money' is a money that has intrinsic value as a commodity. Such money becomes ' good money' or good money because if it loses its face value by law (legal-tender law) then the money will still be able to be exchanged with the actual value of its general content. In other words, good money will be redeemed with the intrinsic value of the metal although the value of his or her face is not worth (by law). It is usually used in any situation where the government is trying to circulate new currencies progressively by combining the old money. According to Gresham's Law, if money in circulation contains both good money and bad money, then bad money will drive out good money due to bad money that consists of bad coin containing less bullion than other coins holding.This is because humans will be more likely to spend, deliver and release money from ' bad money ' from ' good money'. While ' good money ' will be kept and the result of ' bad money ' will remain in circulation while ' good money ' will be out of circulation. For example, a gold coin is required to pay a better price for a bullion. Normally, humans will take advantage of the opportunity to get bullion as the coins are more valuable than the bullion itself. Easy for a coin-making makes bad money as cheap money and thus will increase the offering on the money. Prices increased, including prices for the bullion. It will be more valuable than more heavy coins, where humans remove it from circulation. Cheap is not bad for every coin, and next bad money pushes out good money. According to Marquard (1994), the flow of money movements under Gresham's Law was proved based on the history of the previous currency system. Where the circulation of two types of currency simultaneously will see one currency is accepted as an intermediary tool and one of them is stored. The currency is stored usually with good value savings.

The implementation of gold currency is in two circumstances; is physically used (FDE) and is also backed up (SDE). The FDE mechanism is based on the monetary system that uses metal physique as a currency is called bimetallic system which has dominated the world monetary system starting from 1815 until 1873 (Bordo 1992). This system was used in Roman and Persian times as well as early Islamic times. According to Oppers (2000), bimetallic system is a system that uses two commodities normally gold and silver as currency standards and is created as a payment tool.The arrangement ratio in bimetallic systems are stated in weight weights (gram). For example, 16 ounce of silver equivalent to 1 ounce of gold, described as 16 ratios 1 or 16:1. After the time of bimetallic, a standard gold system or gold standard was introduced from 1873 to 1914 . However, the physical currency of gold is still maintained and used as a tool with pounds sterling banknotes. During the era of use of the bimetellic currency and the gold standard of nearly 1500 years have witnessed a period of currency value stability and the harmonious currency system. Historical studies have also proved that the period was mainly in 1833 until 1925 of the inflation rate was zero (Jasram 1997).

The mechanism of using dinars gold Backup (SDE) means that today's paper currency is used as usual but, its value is backed at the gold dinars value. The SDE system is similar to the concept of the Bretton Woods system. However, there is little variation when the base currency setting for SDE is dinars gold is not US dollar as practiced by Bretton Woods. While the main backup of the currency does not depend on gold simply, but is fixed with GDP yield. The proposal towards restoring the implementation of the Bretton Woods system was mentioned by Robert Zoellick, president of the World Bank in 2010. He has stated the same in the Financial Times News on 7 November 2010. His phrases are as follows:

...we need to Bretton Woods II, is likely to need to involve the dollar, the euro, the yen, the pound and a renminbi that moves towards internationalisation and then an open capital account.... The sistem should also consider employing gold as an international reference point of market expectation about inflation, deflation and future 
currency values... The scope of the changes since 1971 certainly matches those between 1945 and 1971 that prompted the shift from Bretton Woods I to II... Although textbooks may view gold as the old money, markets are using gold as an alternative monetary asset today...

Hayek (1976) has also supported a gold-based currency backup system. As the statement has been mentioned by him:

...significantly, it was only during the rise of the prosperous modern industrial sistems and during the rule of the gold standard, that over a period of about two hundred years...prices were at the end about where they had been at the beginning (em phasis added) (1976, p.9)... With the exception only of the 200-year period of the gold standard, practically all governments of history have used their exclusive power to issue money in order to defraud and plunder the people $(1976, p .16)$...

\section{Issues related to Gresham's Law}

Gresham's Law created two different prepositions:

a) Different intrinsic values between two currencies cannot be circulating at once, except when the amount of one currency is limited. Another currency will continue to be a money, and

b) Only bad or weak money will be circulating in society compared to the other money. Such situations have been happening in the United States in the nineteenth century.

Although there is no endorsement of empirical Grehams's Law, but logically when two currencies are circulating simultaneously with different intrinsic values will remove valuable currencies. Indeed, the Law of ' bad money drive out good money ' has long been held as an principle of currency mastery. However, Studies performed Rolnick \& Weber (1986) have shown otherwise. According to the Gresham's Law, bad money and good money will be circulating together, bad money is the price determined equal to face value, while good money has an intrinsic value exceeding the face value. Study Rolnick \& Weber (1986) states that the expulsion of good money came out is something positive in the monetary system.

According to Rolnick \& Webrer (1986) Although there are legal laws, people will always use good money as a currency, but at the value of the bullion. For example, a debt provider with a claim of US $\$ 100$. If the debtor offers bad money denominated in $\$ 100$, and the legal status has forced the debt provider to accept the offer; The debt provider will not be able to be an suitability for no payment. But what if the debtor offers good money in an denomination value of US $\$ 95$ but a bullion form is less than US $\$ 100$. Humans will tend to choose bullion i.e. good money compared to US $\$ 100$ banknotes.Legal laws cannot prevent the debt provider from receiving such offers, and both parties have the reason to seek a method of correcting the law. Rolnick and Weber (1986) also focus on price not on quantity as a magnitude for the suitability that storing good money is worth lower as a coin than as a bullion. They do it in a quantity adjustment, but ' just cost to use good money at a significant premium level'.

The opinion from Rolnick \& Weber (1986) is supported by studies made by Reisman (1990). Reisman (1990) denies the theory of the Gresham's Law if a healthy competition situation occurs in both the currency system as it has occurred in 1965. For example; Silver coins that are still in circulation in the United States at the time are one piece of silver (7 ounces) worth US $\$ 10$ and US $\$ 10$ banknotes can be converted to buy a number of same stuff.However, in the mid-1980 the same item can be purchased with a value of US $\$ 30$ banknotes, but if evaluated with the value of silver with a silver piece $\$ 10$ (equivalent to a value of 7 ounces of silver, at that time US \$6/ounce) equivalent to

U.S. $\$ 42$ banknote if converted with banknote value. Thus, the price of goods of US $\$ 30$ represents less than $3 / 4$ piece of silver. On the other hand, if seen from the face value of the coin, is less than US $\$ 7.50$ in the form of silver coin.

If trade essentially can distinguish the value of the banknotes and coins worth, they may be able to sell the same items, whether with US $\$ 30$ in banknote and less US $\$ 7.50$ in the form of silver coins.

According to Reisman (1990) again, the same principle was implemented for the use of old gold coins. In 1933, the United States had gold coins known as ' Double Eagles ' where it had a face value of US \$20 and contains 1 ounce of pure gold. The price of gold today is nearly reaching US $\$ 400$ for one ounce of gold, a new car sold of U.S. $\$ 12000$ in the form of banknotes can be owned with approximately US $\$ 600$ in the form of gold coins. If the banknotes are constantly printed without a backup, there will be depreciation even though quantified in the market increasingly much.

Hence, Rolnick \& Weber (1986) and Reisman (1990) believed that the community would require pension calculations in the form of gold or silver metals. Lenders want money to be evaluated in the form of gold and silver. Then of course, the need for an increase in metal demand and reduces demand on banknote. 
In the event the price of the banknote has always increased, but fixed or likely to occur in a metal currency, the demand on the banknote will eventually be deleted all. As man prefers to value money (intrinsic) than bad money (without its intrinsic value). Under this free competition, only one place of banknotes can be in circulation i.e. the banknotes can redeem the metal currency or with other words by backing up the value to gold. These discussions raised a dispute with the Gresham's Law. It shows under the free competition of two currencies ' good money ' eliminates ' bad money ' instead of the Gresham's Law stating that ' bad money ' eliminates good money '. Gresham's Law cannot function properly if there are independent competition in both currencies. What is eliminating ' good money ' is a fact where society is prohibited from receiving it in the form of value now. Today the value of gold and silver values based on the banknotes value (based on US dollar) is not the setting of gold and silver value naturally. For example, to purchase new cars of U.S. $\$ 12000$, with ' Double Eagle ' is a US \$600 coin, this is the necessary amount based on the face value of US $\$ 12000$. In other words, he needs payment with gold is the current gold rating of U.S. $\$ 240000$ to get something less than US $\$ 12000$. Meanwhile, buyers paying with silver coins for example for 3/4 silver necessities, should look at the current valuation of US $\$ 126$ to get less items than US $\$ 30$. If seen from this point, it is not impossible to ' good money ' (worth) to stop in circulation as a currency. Humans will not sacrifice what is better when it is made resemblance to the worse. But when better can be done with better value, as gold and silver coins can be circulating with its intrinsic value, then it is not impossible, ' good money ' will be able to delete ' bad money '(Reisman, 1990).

However, if seen in the context of today, the theory of currency movement is still in favour of the Gres"s Law, which is ' Bad Money Drive Out Good Money ' as long as the banknote system dominated the world monetary system. However, the theory highlighted by Rolnick \& Weber (1986) and Reismen (1990) ' Good Money Drive Out Bad Money ' became the aspiration and amplifier in order to realize the implementation of a gold-backed currency system. The theory of ' Good Money Drive Out Bad Money ' should be given attention in the effort to develop gold-based currency systems. This is because of the existing currency, the banknotes have no intrinsic value while the proposed gold dinars clearly has its intrinsic value. Hence, when the use of two currencies varies greatly in terms of intrinsic value, will include 'Good Money Drive Out Bad Money'.

\section{The Gold Dinars System in The Gresham's Law Theory}

\subsection{Physical Gold Dinar System (FDE)}

Gresham's Law will occur in two instances:

\section{(I) Simultaneous Use of Gold Dinar with Banknote}

Gold dinar is ' good money ' for its intrinsic value while banknotes are ' bad money ' because there are no valuable commodity backups. Gold dinar has a steady value due to its limited availability and the price of gold will be increasing. In contrast to the fiat money that will always have a weakening value based on the annual inflation percentage. Hence, the public will hold and keep the gold dinars as the future asset (investment) and use the banknotes as the currency circulating. Eventually the golden dinars will be removed from the market and paper money will be a single circulating currency.

\section{(i) Use of Gold Dinar and Silver Dirham (Bimetallic)}

Gresham's Law will also occur if only two of these metals are circulating in the market. This is because gold dinars can be categorized as ' good money ' while, silver dirham will be ' bad money '.

If these two metals are used concurrently, there is an official exchange ratio as unit currency. If the official exchange ratio as a unit of money between these two metals is $15: 1$, its meaning to get one ounce of gold by 15 ounce of silver is needed.However, this exchange ratio can change in the market. The ratio of exchange in the market is often associated with an unofficial ratio of the metal as a commodity. The changes often occur will be the main problem in the bimetallic system. The unofficial ratio will depend on the supply and demand of metals. When the supply of one of these metals will change then, the exchange ratio is unofficial in both metals will be changed. If the silver supply increases, the price will deteriorate and the ratio may be variable to 16:1.This unofficial ratio can result in a profit by converting silver coins to gold coins based on the official exchange ratio of the 15:1 currency unit. Then the gold coins were tossed making gold bars and converted to silver in the market at a ratio of 16:1. Based on this transaction, 1 ounce of silver gains for every ounce of gold is flatited. After that surrender the silver ingot to the authorities to get the gold coins 15:1.This process can be repeated repeatedly to earn profit. If this transaction occurs in full will remove the gold coins in circulation immediately and only stay silver coins as currency. Finally the process resulted in ' bad money ' (silver coins which declined as a result of the increase in supply) would remove ' good money ' (gold coins) from circulation.

\subsection{Back by Gold System (SDE)}


Gresham's Law doesn't happen in the backup system because gold money (dinars gold) is not used as a currency being circulating. Only paper currency (as now) are circulating in the market as currency. Therefore, there does not happen to use two different forms of currencies simultaneously in the economic system.

\section{Conclusions}

The Gresham ' Law ' Bad Money Drive Out Good Money ' is a theory that explains the simultaneous use of currencies that do not have an intrinsic value (bad money) with a currency that has an intrinsic value (good money) in the market will mess up the currency with its intrinsic value (good money). The banknote currency is categorized as ' bad money ' currency while gold dinar is ' good money '. Therefore, based on this theory of the banknotes and gold dinar cannot be used concurrently in the market as the official currency. However, there are other theories that deny the theory of the Gresham's Law, where such theory explains that the ' Good Money Drive Out Bad Money '. The theories highlighted by Rolnick \& Weber (1986) and Reismen (1990) are effective in the free exchange system. This theory also becomes a motivation and aspiration to realize the implementation of the gold dinars based currency system.

\section{Acknowledgments}

Acknowledgement to research grant project; GUP-2017-119 Research Grant University (UKM)

\section{References}

Bordo, Michale. D. (1993) The gold standard, Bretton Woods and other monetary regimes: a historical appraisal. Federal Reserve Bank of St. Louis Review, March.

Bordo, Michale.D. (1992) The gold standard and other monetary regimes. (Research Summaries). NBER Reporter (Research Summaries), March 22.

Greenfield, R. L., \& Rockoff, H. (1995) Gresham's Law in nineteenth-century America. Journal of Money, Credit \& Banking 27 (4): 1086-1011.

Mundell, R. A. (1997) The International Monetary Sistem in The 21th Century: Could Gold Make a Comeback? Lecture delivered at St. Vincent College, Lethrobe, Pennsylvania. March 12.

Hasan, Ahmad. (1999) Al-Awraq al-Naqdiyyah al-Iqtisadi al-Islami: Qimmatuha wa Ahkamuha. Damshiq: Dar alFikr.

Selgin, G. (1996) Salvaging Gresham's Law: The good, the bad, and the illega. Journal of Money, Credit \& Banking 28 (4): 637-650.

Jastram, R. W. (1997)The Golden Constant: The English and American Experience 1560-1976. Barkeley: University of California.

Hayek, A. F. (1976)Choice in Currency: A Way to Stop Inflation London. London: The Institute of Economic Affairs.

Rolnick, A. J. \& Weber, W. E. (1986) Gresham's Law or Gresham's Fallacy? Journal of Political Economy (94): 99-185.

Reisman, G. (1990)Capitalism: A Treatise on Economics. Ottawa, Canada: Jameson Books.

SalmyEdawati Yaacob \& Sanep Ahmad (2014) Return to Gold-Based Monetary System: Analysis Based On Gold Price And Inflation Asian Social ScienceVol 10 (7) page 18-28

SalmyEdawati Yaacob (2012)World Applied Sciences JournalStudy of Implementation Gold Dinar as CurrencyVol 20 (7) 2012 page 1014-1023 